\title{
Sectoral Contribution on the Economic Growth in Manipur
}

\author{
${ }^{1}$ R. K. Radhesana, ${ }^{2}$ E. Bijoykumar Singh \\ 1. Research Scholar, Department of Economics, Manipur University, Imphal \\ 2. Professor, Department of Economics, Manipur University, Imphal
}

\begin{abstract}
Under the research question that what are the sectors contributing the economy, the current NSDP in Manipur? an empirical study has been carried out using the retrospective information during the period from 1970 to 2007. Regression analysis explores the sectors influencing the states economic growth are found to be agriculture and allied $(P<0.01)$, science technology and environment $(P<0.05)$, rural development, SAP and cooperation ( $P<0.05)$, social service $(P<0.01)$, irrigation and flood control $(P<0.01)$, and industry and mining $(P<0.05)$ through SPSS. The results arrived at in this investigation may be the baseline information for the economic analysis in NE region of India.
\end{abstract}

Key Words: NE states, agriculture, social service, science and technology, regression models, $P$-value

\section{Introduction}

Economic growth is conventionally measured as the percent rate of increase in real gross domestic product (GDP) referring to growth of potential output - production at full employment which is due to growth in aggregate demand. It shows how the countries can advance their economies. Though, variation exited in many countries, the infrastructure provision induces long run economic growth (Canning and Pedroni, 2004). It is further emphasized by Balázs et al. (2009) that the empirical relationship between infrastructure and long run economic growth is strong specifically the investment on telecommunication and electricity sector. It is seen in the postwar economic growth of the East Asian newly industrialized economies (NIEs) that Hong Kong, South Korea, Singapore and Taiwan (Kim and Lau, 1994). Based on the world development indicators, Mukhopadhyaya (2002) also highlighted that the economies of the high income countries like USA, Japan and France have been dominated by the service sector, as the share of this sector to GDP was above 50\% in these countries in 1980 and these economies are depicting a rising trend and share of service sector has reached to above $60 \%$ in 1990 . The analysis of the sectoral composition of GDP for the period of 1950-2000 brings out the fact that during the process of economic development in India a growing tertiarization of the structure of production has been taking place. Based on the National Accounts Statistics (NAS) released by the Central Statistical Organisation (CSO), it is found that the share of agricultural sector in real GDP at 1993-94 prices declined from $55.5 \%$ in the 1950 s to $28.7 \%$ in 1990 and the share of industry and services increased from $16 \%$ to $27.1 \%, 28.1 \%$, and $44.2 \%$ respectively during the same period.

The low economic growth in North Eastern (NE) states of India is caused by higher variability and inadequate infrastructure and also non utilisation of central Govt. funds for productive purposes (Roy and Dastidar, 2011). The per capita Net State Domestic Product (NSDP) at current prices for the year 1993-94 in the region is lower than per capita net domestic product at the national level except Arunachal Pradesh so that the NE region is less economically developed than the rest of India (Srivastav, 2006). This region is rich in natural resources like land, water and forests resources, of which larger proportion is underutilized. Manipur is relatively complex in exploring the sectors contributing the economic growth and hence the present study aims to investigate the sectoral contribution in NSDP of the state.

\section{Materials and Methods}

Using the data for thirty-eight years say from 1970 to 2007, furnished by the Department of Economics and Statistics (Govt. of Manipur), regression analysis has been carried out to check the share contribution of the ten sectors on state economy through SPSS. It is to test the null hypothesis $\left(H_{0}: \beta_{i}=0\right.$, each regression coefficient is zero) that the NSDP is not influenced by the sectors as against the alternative hypothesis $\left(H_{I}\right.$ : $\beta_{i} \neq 0$ ) that the NSDP is significantly influenced by the sectors. Considering the response variable to be NSDP at current prices of a year measured in terms of lac rupee, the improvement level in the NSDP $(Y)$ is assumed to be functionally related with only ten sectors of the state economy. They are agriculture and allied $\left(X_{1}\right)$, rural development, SAP and cooperation $\left(X_{2}\right)$, irrigation and flood control $\left(X_{3}\right)$, energy $\left(X_{4}\right)$, industry and mining $\left(X_{5}\right)$, transport and communication $\left(X_{6}\right)$, science technology and environment $\left(X_{7}\right)$, general 
economic service $\left(X_{8}\right)$, social services $\left(X_{9}\right)$ and general services $\left(X_{10}\right)$. The sectors are also measured in terms of lac rupee. Precisely, $Y=f\left(X_{1}, X_{2}, X_{3}, \ldots X_{10}\right)$.

\section{Analysis and Results}

Here, the Net State Domestic Product (NSDP in lac rupee) of Manipur is functionally related with the proportions (in lac rupee) of ten sectors of the state's economy that is background variables, defined by agriculture and allied, rural development, SAP and cooperation, irrigation and flood control, energy, industry and mining, transport and communication, science technology and environment, general economic service, social services and general services. While bivariate regression analysis is performed, it is evident that the null hypothesis is rejected in the sense that all regression coefficients $\left(\beta_{i}\right)$ can not be zero. Each and every sector has significant impact on the NSDP irrespective of the effects of other sectors of economy. It is evidenced by tvalues with their corresponding P-values, which is manifested in Table - 1. The degree of model fit $(F)$ and degree of explanation $\left(R^{2}\right)$ of the sectors in the total variation in NSDP are also observed in the same table.

Only three sectors viz., agriculture and allied $(\mathrm{P}<0.01)$, rural development SAP and Cooperation $(\mathrm{P}<0.05)$ and science technology and environment $(\mathrm{P}<0.05)$ have been observed to have their statistically significant contribution on the variation in NSDP in the state. The significant effects can be explored after having natural $\log$ transformation of all the sectors due to statistical reason of better model fit. After adjusted the joint effects of other nine sectors, to each increment of Rs. 1 lac in the log of agriculture and allied sector in a year, the $\ln (\mathrm{NSDP})$ will reduce by Rs. 0.93 lac during the year in Manipur $(\beta=-0.93$ with $95 \% \mathrm{CI}$ : $(-0.22)-(-$ $0.63)$. This high negative impact $(\mathrm{P}<0.01)$ might perhaps be due to the linear effect other sectors under investigation. It is only statistical view. The impact of $\ln$ (rural development, SAP and co-operation) on the $\ln (\mathrm{NSDP})$ is found to be $0.18(\mathrm{P}<0.05)$. It may be interpreted as to each annual increment of Rs. 1 lac in 'rural development, SAP and co-operation', the NSDP may be increased by Rs. 0.18 lac during the year. This statistically significant result can be achieved after adjusted the joint effects of other nine sectors of economy in the state. In this way, after controlled the effects of other nine sectors, science and technology also give positive impact on the NSDP $(P<0.05)$, manifested in Table - 2. Apart from their statistical significance, under the multivariate analysis, the fitted regression model may be expressed as the following Equation. In this model, the total variation in the $\ln (\mathrm{NSDP})$ has been explained $99 \%$ by the ten sectors under analysis.

$\ln (N S D P)=\quad 8.75-0.93 x \ln$ (agriculture and allied $)+0.18 x \ln ($ Rural development, SAP and cooperation $)+0.25 x \ln ($ Irrigation and flood control $)+0.11 x \ln ($ Energy $)+0.20 x$ $\ln$ (Industry and mining) $-0.09 x \ln$ (Transport and communication) $+0.24 x$ $\ln ($ Science technology and environment $)-0.05 x \ln$ (General economic service) + $0.47 x \ln ($ Social service $)+0.03 x \ln ($ General service including NHPS)

To investigate the most important sectors influencing the NSDP, the regression model is further analysed by using Stepwise method which is shown in the Table - 3. The analysis is carried out in six steps say from Model 1 to Model 6. In multiple regression model, only three sectors are found to have their significant impacts on NSDP but it is six sectors in stepwise method. It reveals that only six sectors of economy have significant contribution on the variation in NSDP. They are i) social service, ii) agriculture and allied, iii) science technology and environment, iv) irrigation and flood control, v) industry and mining and vi) rural development, sap and co-operation. In statistical view, the regression model can be fitted with the important six sectors. In the last model that is Model -6 , three sectors namely social service, $(\beta=0.42$ with $95 \%$ CI: $0.22-0.63)$, agriculture and allied (-0.88 with $95 \%$ CI: -1.08 to -0.68$)$ and irrigation and flood control (0.31 with 95\%CI: 0.16-0.46) have been observed to be highly influential on the dynamics of Net State Domestic Product each at least at 0.01 probability level of significance $(\mathrm{P}<0.01)$. However the significant results are obtained after transforming the values of all sectors and that of NSDP into natural logarithm. The remaining three sectors - science technology and environment, industry and mining and rural development, SAP and Co-operation level of education have statistically significant impacts $(\mathrm{P}<0.05)$ on the regulation of NSDP.

The stepwise regression models may be written as the following.

Step - 1 Model $\left(\mathrm{F}=103.72, \mathrm{P}<0.001, \mathrm{R}^{2}=85 \%\right)$ :

$$
\ln (N S D P)=3.31+0.96 \times \ln (\text { social service })
$$

Step - 2 Model $\left(\mathrm{F}=92.28, \mathrm{P}<0.001, \mathrm{R}^{2}=91 \%\right)$ :

$\ln (N S D P=\quad 6.73+1.15 \times \ln ($ (social service $)-0.67 \times \ln$ (agriculture and allied)

Step - 3 Model $\left(\mathrm{F}=104.27, \mathrm{P}<0.001, \mathrm{R}^{2}=95 \%\right)$ :

$\ln (N S D P=\quad 7.92+0.87 x \ln ($ social service $)-0.71 x \ln$ (agriculture and allied)

$+0.33 x \ln$ (science technology and environment) 


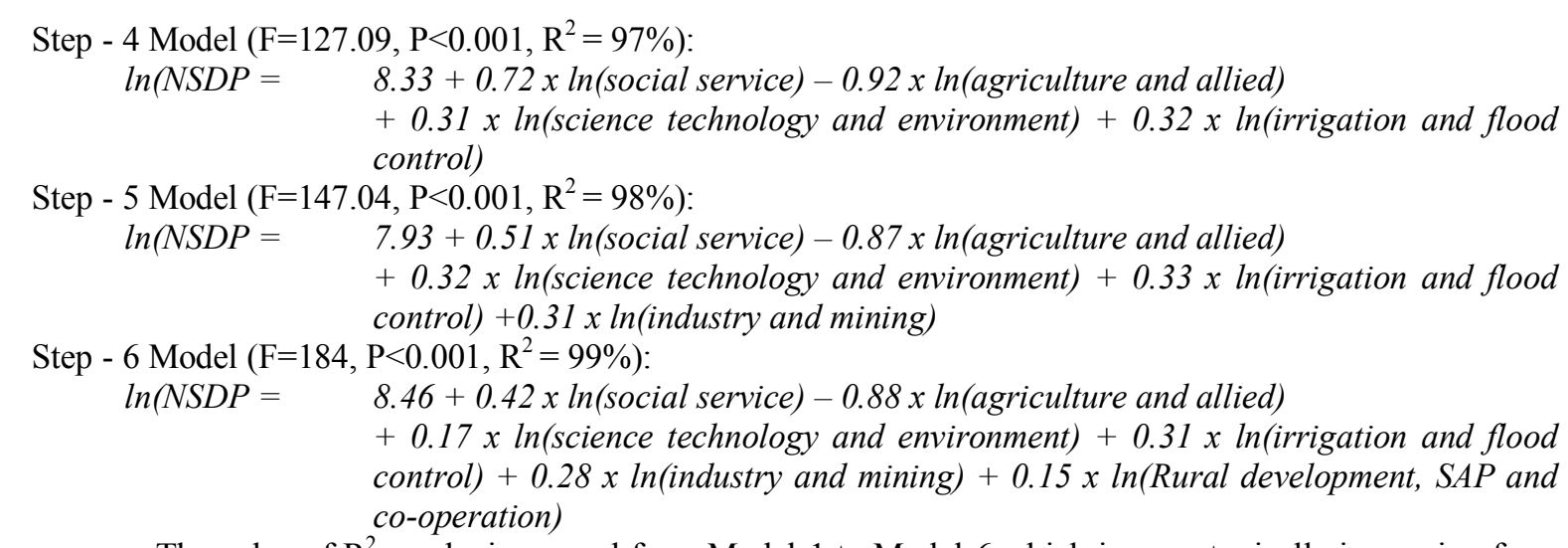
$85 \%$ to $99 \%$. In the first model (Step-1), social service can explain $85 \%$ of the total variations in the NSDP in the present analysis. In one sense, if social sector is increased by Rs. 1 lac, the NSDP will correspondingly increase Rs. 0.96 lac irrespective of the joint effects of other sectors. The degree of explanation of the model can also be improved to be $92 \%$ in the Model-2 with the two sectors namely social service and agriculture and allied sector. In the second model that is Step - 2, when Rs. 1 lac is increased in the $\ln$ (social service), the corresponding $\ln$ NSDP may be increased by Rs. 1.15 lac after adjusted the effect of agriculture and allied sector. It is shown in Table - 3. While adjusted the effect of social service sector, the agriculture and allied sector has a significant negative impact on NSDP. It may also be observed that at each level of analysis in the stepwise method, the agriculture and allied sector has negative impact on NSDP. This unique finding may be thought to be caused by the confounded effects of the other sectors under consideration. In this statistical view, the most important sectors influencing NSDP have been observed to be social service, agriculture and allied, science technology and environment, irrigation and flood control, industry and mining and rural development, SAP and co-operation.

\section{Discussion and Conclusion}

In the present investigation, the ten sectors are assumed to be influential on the state economy in Manipur which is advocated in bivariate regression models. However, only three sectors viz., agriculture and allied, science technology and environment, and rural development, SAP and co-operation have their statistical significant contribution on the dynamics of NSDP during the thirty-eight years (1970-2007) applying multiple regression model while controlling the joint effects of other nine sectors to each explaining each significant sector. Besides, another three sectors - social service, irrigation and flood control, and industry and mining can be added to the set of significant sectors of the NSDP in the stepwise regression models. Thus, the six sectors namely agriculture and allied, science technology and environment, rural development, SAP and co-operation, social service, irrigation and flood control, and industry and mining can be detected to be the important sectors to improve the NSDP in Manipur. But, the findings of Srivastav (2006) highlighted that NE states has the trend of reduction in the agriculture sector and increase in the service sector to the NSDP during the period from 1980-81 to 1993-94 and further observed that the major contribution towards the growth of service sector is due to the increase in public administration expenditure. Meanwhile, Roy and Dastidar (2011) observed that the average growth of NE states falls continuously from 11.13 to 9.58 during the period of 2000-01 to 2005-06 due to low industrialization, subsistence nature of agriculture, poor infrastructure, insurgency and utilization of most of the Central Govt. funds for consumption purposes and not for further income generation. The situation in advanced states is that growth has increased continuously from 7.28 to 13.78 during the same period. In their findings, among the NE states some states such as Manipur and Arunachal Pradesh growth is negative in the year 2000-01 and 2002-03 respectively while there is negative growth only in Gujarat in 2000-01 among the advanced states during the period of our study.

\section{References}

[1]. Balázs E, Tomasz K, Douglas S. Infrastructure and growth: Empirical evidence, CESifo Working Paper, 2009; No. 2700

[2]. Canning D and Pedroni P. The Effect of Infrastructre on Long Run Economic Growth. Harvard University, $2004:$ 1-30.

[3]. Kim JI and Lau LJ. The sources of economic growth of the East Asian newly industrialized Countries. Journal of Japan International Economics, 1994; 8: 235-271.

[4]. Mukhopadhyaya S. Globalization and Indian service sector. Economic and Political Weekly, 2002; 38(40): 4097-98.

[5]. Roy H and Dastidar SG. Dynamics of economic growth: a study of some selected Indian states. Asian Journal of Business and Economics, 2011; 1 (1): 1-44.

[6]. Srivastav N. industrial development in the North Eastern states of India: The case of service industries, The ICFAI journal of Industrial Economics, 2006; 3(4): 60-69. 
Table - 1: Bivariate Regression Analaysis on $\ln (\mathrm{NSDP})$ with ten sectors

$$
\left[\ln (N S D P)=\alpha+\beta \ln \left(X_{i}\right), \quad i=1,2,3, \ldots, 10\right]
$$

\begin{tabular}{|c|c|c|c|}
\hline$\alpha+\beta \ln \left(X_{i}\right)$ & t-value of $\beta$ & Model $F$-value & $R^{2}$ \\
\hline $5.64+0.78 \times \ln ($ Agriculture and Allied) & $7.43(\mathrm{P}<0.01)$ & $55.20(\mathrm{P}<0.01)$ & $61 \%$ \\
\hline $8.20+0.55 \times \ln ($ Rural Dev, SAP \& Co-Op) & $9.53(\mathrm{P}<0.01)$ & $90.72(\mathrm{P}<0.01)$ & $81 \%$ \\
\hline $4.78+0.85 \times \ln ($ Irrigation \& Flood Control) & $14.85(\mathrm{P}<0.01)$ & $220.45(\mathrm{P}<0.01)$ & $86 \%$ \\
\hline $5.17+0.84 \mathrm{x} \ln ($ Energy) & $11.15(\mathrm{P}<0.01)$ & $124.25(\mathrm{P}<0.01)$ & $78 \%$ \\
\hline $4.67+1.01 \times \ln ($ Industry \& Mining) & $22.39(\mathrm{P}<0.01)$ & $501.65(\mathrm{P}<0.01)$ & $94 \%$ \\
\hline $2.01+1.23 \times \ln ($ Transport \& Communication) & $17.10(\mathrm{P}<0.01)$ & $292.47(\mathrm{P}<0.01)$ & $89 \%$ \\
\hline $3.41+0.95 \times \ln ($ Social Service $)$ & $28.43(\mathrm{P}<0.01)$ & $49.25(\mathrm{P}<0.01)$ & $96 \%$ \\
\hline $7.93+0.85 \times \ln ($ Science Tech. \& Environment) & $7.12(\mathrm{P}<0.01)$ & $110.34(\mathrm{P}<0.01)$ & $73 \%$ \\
\hline $7.35+0.69 \times \ln ($ General Economic Service $)$ & $7.61(\mathrm{P}<0.01)$ & $57.91(\mathrm{P}<0.01)$ & $64 \%$ \\
\hline $6.02+0.85 \times \ln ($ General Service inc. NHPS $)$ & $10.50(\mathrm{P}<0.01)$ & $808.09(\mathrm{P}<0.01)$ & $77 \%$ \\
\hline
\end{tabular}

Table -2: Multiple Regression coefficients of sectors on $\ln ($ NSDP)

\begin{tabular}{|l|c|c|c|}
\hline \multicolumn{1}{|c|}{$\ln$ of Sectors } & $\beta$ & $\mathrm{t}-$ values & $95 \% \mathrm{CI}$ for $\beta$ \\
\hline (Constant) & 8.75 & $11.44(\mathrm{P}<0.01)$ & $7.02,10.48$ \\
\hline Agriculture and allied & -0.93 & $-7.02(\mathrm{P}<0.01)$ & $-1.22,-0.63$ \\
\hline $\begin{array}{l}\text { Rural development, SAP and co- } \\
\text { operation }\end{array}$ & 0.18 & $2.84(\mathrm{P}<0.05)$ & $0.04,0.33$ \\
\hline Irrigation and flood control & 0.25 & $2.18(\mathrm{P}>0.05)$ & $-0.01,0.52$ \\
\hline Energy & 0.11 & $1.54(\mathrm{P}>0.05)$ & $-0.05,0.28$ \\
\hline Industry and mining & 0.20 & $1.20(\mathrm{P}>0.05)$ & $-0.18,0.59$ \\
\hline Transport and Communication & -0.09 & $-0.53(\mathrm{P}>0.05)$ & $-0.47,0.29$ \\
\hline $\begin{array}{l}\text { Science technology and } \\
\text { environment }\end{array}$ & 0.24 & $2.97(\mathrm{P}<0.05)$ & $0.06,0.42$ \\
\hline General economic service & -0.05 & $-0.83(\mathrm{P}>0.05)$ & $-0.19,0.09$ \\
\hline Social service & 0.47 & $1.92(\mathrm{P}>0.05)$ & $-0.09,1.03$ \\
\hline General service including NHPS & 0.03 & $0.40(\mathrm{P}>0.05)$ & $-0.13,0.19$ \\
\hline
\end{tabular}

Model Diagnostics: $\mathrm{F}=108.65(\mathrm{P}<0.01), R^{2}=0.99$

Table - 3: Stepwise regression analysis on In (NSDP)

\begin{tabular}{|c|c|c|c|c|}
\hline Step & ln of Sectors & $\beta$ & $\mathrm{t}$ - values & $95 \% \mathrm{CI}$ for $\beta$ \\
\hline \multirow[t]{2}{*}{1} & (Constant) & 3.31 & $3.84(\mathrm{P}<0.01)$ & $1.49,5.12$ \\
\hline & Social service & 0.96 & $10.18(\mathrm{P}<0.01)$ & $0.77,1.16$ \\
\hline \multirow[t]{3}{*}{2} & (Constant) & 6.73 & $5.76(\mathrm{P}<0.01)$ & $4.27,9.20$ \\
\hline & Social service & 1.15 & $12.81(\mathrm{P}<0.01)$ & $0.96,1.34$ \\
\hline & Agriculture \& allied & -0.67 & $-3.58(\mathrm{P}<0.01)$ & $-1.06,-0.27$ \\
\hline \multirow[t]{4}{*}{3} & (Constant) & 7.92 & $8.10(\mathrm{P}<0.01)$ & $5.85,9.99$ \\
\hline & Social service & 0.87 & $8.14(\mathrm{P}<0.01)$ & $0.64,1.10$ \\
\hline & Agriculture $\&$ allied & -0.71 & $-4.82(\mathrm{P}<0.01)$ & $-1.02,-0.40$ \\
\hline & Science tech. \& env. & 0.33 & $3.43(\mathrm{P}<0.01)$ & $0.13,0.54$ \\
\hline \multirow[t]{5}{*}{4} & (Constant) & 8.33 & $10.61(\mathrm{P}<0.01)$ & $6.66,10.01$ \\
\hline & Social service & 0.72 & $7.41(\mathrm{P}<0.01)$ & $0.51,0.92$ \\
\hline & Agriculture $\&$ allied & -0.92 & $-6.89(\mathrm{P}<0.01)$ & $-1.20,-0.63$ \\
\hline & Science tech. \& env. & 0.31 & $4.01(\mathrm{P}<0.01)$ & $0.14,0.47$ \\
\hline & Irrigation \& flood control & 0.32 & $3.23(\mathrm{P}<0.01)$ & $0.11,0.53$ \\
\hline \multirow[t]{6}{*}{5} & (Constant) & 7.93 & $11.79(\mathrm{P}<0.01)$ & $6.49,9.38$ \\
\hline & Social service & 0.51 & $4.63(\mathrm{P}<0.01)$ & $0.28,0.75$ \\
\hline & Agriculture \& allied & -0.87 & $-7.76(\mathrm{P}<0.01)$ & $-1.11,-0.63$ \\
\hline & Science tech. \& env. & 0.23 & $3.34(\mathrm{P}<0.01)$ & $0.08,0.38$ \\
\hline & Irrigation \& flood control & 0.33 & $3.95(\mathrm{P}<0.01)$ & $0.15,0.51$ \\
\hline & Industry \& Mining & 0.31 & $2.73(\mathrm{P}<0.05)$ & $0.07,0.55$ \\
\hline \multirow[t]{7}{*}{6} & (Constant) & 8.46 & $14.58(\mathrm{P}<0.01)$ & $7.21,9.72$ \\
\hline & Social service & 0.42 & $4.44(\mathrm{P}<0.01)$ & $0.22,0.63$ \\
\hline & Agriculture $\&$ allied & -0.88 & $-9.57(\mathrm{P}<0.01)$ & $-1.08,-0.68$ \\
\hline & Science tech. \& env. & 0.17 & $2.74(\mathrm{P}<0.05)$ & $0.04,0.30$ \\
\hline & Irrigation \& flood control & 0.31 & $4.51(\mathrm{P}<0.01)$ & $0.16,0.46$ \\
\hline & Industry \& Mining & 0.28 & $3.02(\mathrm{P}<0.05)$ & $0.08,0.48$ \\
\hline & Rural dev., SAP \& co-op. & 0.15 & $2.83(\mathrm{P}<0.05)$ & $0.03,0.26$ \\
\hline
\end{tabular}

